\title{
Production of a Bioherbicide Agent in Liquid and Solid Medium ANd In a Biphasic Cultivation System ${ }^{1}$
}

\author{
Produção de um Agente Bioherbicida em Meio Líquido, Sólido e em Sistema Bifásico de Cultivo
}

MORAES, C. ${ }^{2}$, MONTEIRO, A.C. ${ }^{2}$, MACHADO, A.C.R. ${ }^{2}$, BARBOSA, J.C. ${ }^{2}$, and MOCHI, D.A. ${ }^{2}$

\begin{abstract}
The use of fungi in weeds control programs depends upon the conidia production in large scale. Therefore, this study aimed to evaluate liquid and solid culture media and the cultivation by biphasic system for the conidia production of Bipolaris euphorbiae Muchovej \& Carvalho a specific pathogen of Euphorbia heterophylla. The liquid media were obtained from agro-industrial waste or by-products, and the solid media were prepared with mixtures of grains and grain derivatives. The liquid medium made with sugar cane molasses stood out from the others because it provided great sporulation $\left(23 \times 10^{4}\right.$ conidia $\mathrm{mL}^{-1}$ of medium), conidial viability (99.7\%), and formation of mycelial fungal biomass $\left(1.26 \mathrm{~g} 100 \mathrm{~mL}^{-1}\right.$ of medium). On solid media conidial production was markedly higher than in liquid media, especially the medium composed by a blend of sorghum grain $(40 \%)$ and soybean hulls $(60 \%)$ where the

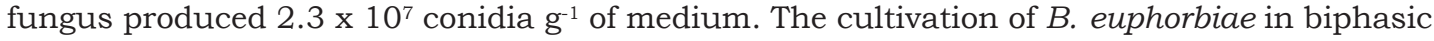
system not promoted a significant increase in the production of conidia. The solid media were more effective for the mass production of fungus and mixtures of grains and derivatives were effective for increasing conidia production.
\end{abstract}

Keywords: Bipolaris euphorbiae, Euphorbia heterophylla, biological control, weed control, fungus production, natural substrates.

RESUMO - O uso de fungos em programas de controle de plantas daninhas depende da produção de conidios em larga escala. Assim, este trabalho teve por objetivo avaliar meios de cultura liquidos e sólidos, bem como o cultivo pelo sistema bifásico, para a produção de conídios de Bipolaris euphorbiae Muchovej \& Carvalho patógeno especifico de Euphorbia heterophylla. O meio líquido foi preparado a partir de resíduos ou subprodutos da agroindústria, e o meio sólido foi obtido de misturas de grãos e derivados. O meio líquido feito com melaço de cana-de-açúcar destacou-se dos demais por ter proporcionado maior esporulação (23 $\times 10^{4}$ conídios $m L^{-1}$ de meio), viabilidade dos conídios $(99,7 \%)$ e formação de biomassa micelial do fungo (1,26 $100 \mathrm{~mL}^{-1}$ de meio). Nos meios sólidos a produção de conídios foi acentuadamente maior que nos meios líquidos, com destaque para o meio composto pela mistura de sorgo em grão (40\%) e casca de soja (60\%), onde o fungo produziu $2,3 \times 10^{7}$ conídios $g^{1}$ de meio. O cultivo de $\boldsymbol{B}$. euphorbiae em sistema bifásico não promoveu aumento significativo na produção de conídios. Os meios sólidos mostraram-se mais eficazes para a produção massal de fungo, e as misturas de grãos e derivados foram eficientes para aumentar a produção de conidios.

Palavras-chave: Bipolaris euphorbiae, Euphorbia heterophylla, controle biológico, controle de planta daninha, produção de fungo, substratos naturais.

\section{INTRODUCTION}

Euphorbia heterophylla infests mainly soybeans, and herbicides have been used to control it. However, continuous use of the trifluralin and metribuzin combination in cultures provides for the selection of resistant plants (Vidal \& Fleck, 1997; Marchiori et al., 2001). Despite all of the technology and chemical controls used, E. heterophylla persists

Recebido para publicação em 13.1.2014 e aprovado em 14.3.2014.

2 Universidade Estadual Paulista, Jaboticabal-SP, Brasil, <karimemoraes@hotmail.com>.

Planta Daninha, Viçosa-MG, v. 32, n. 2, p. 255-264, 2014 
and maintains high densities in commercial soybean fields in Southern and West Central Brazil.

The use of bioherbicides, including the Bipolaris euphorbiae Muchovej \& Carvalho fungus, has been suggested as a strategy for biological control of E. heterophylla (Penariol et al., 2008). The fungus is a pathogen specific to the plant, causing necrotic spots in the stem and leaves and leading to intense defoliation, which may lead to death (Penariol et al., 2008). To be used in an inundative strategy, large quantities of infective propagules must be produced, because large areas will be treated more than once per year (TeBeest, 1984). The production and formulation of microbial agents represents a critical step in advancing the commercial development of prospective biological control products (Kolombet et al., 2008). Large-scale fungus production requires culture media that provide vigorous growth with high sporulation that can be prepared with low-cost substrates that are easy to obtain and handle (Wenzel et al., 2006).

Rice grain is the most used substrate to produce fungi in Brazil. To reduce costs and obtain large quantities of viable propagules, however, studies have been conducted to evaluate the efficiency of other substrates, such as millet, cracked corn, wheat grain (E1 Damir, 2006), birdseed, rice bran, soybean meal, wheat bran, lentil beans, cracked rice, soybeans, soybean mill, crushed wheat, sorghum grain, and crushed sorghum (Wenzel et al., 2006).

Depending on the type of propagules and the species to be produced, fungi can be cultivated using three processes: solid, liquid, and biphasic systems (Alves \& Pereira, 1998). The biphasic system stands out among the methods because it combines the benefits of high biomass production in liquid media with the large production of conidia on solid media (Jenkins \& Goettel, 1997). Although there are many studies involving fungus production, few have addressed the biphasic system of cultivation.

To produce large quantities of $B$. euphorbiae conidia, it is necessary to establish the appropriate media and methods of cultivation. However, such aspects are yet to be sufficiently explored. Therefore, this study aimed to evaluate the conidia production by $B$. euphorbiae in liquid culture prepared from agro-industrial waste or by-products, in solid media made from various grain and grain products, and in a biphasic system composed of a combination of liquid and solid media to provide the optimal fungus production.

\section{MATERIALS AND METHODS}

\section{Fungus}

The fungal isolate used was FCAV\#569 Bipolaris euphorbiae, which was maintained in a stock culture. For its use in experiments, the fungus was grown in Petri dishes containing minimal Pontecorvo medium (Pontecorvo et al., 1953) with composition modified by Penariol et al. (2008). The pH was adjusted to 6 and the fungus grown at $25^{\circ} \mathrm{C} \pm 0.5^{\circ} \mathrm{C}$ over 8 days in a 12 -hour photoperiod.

\section{Liquid media preparation}

Substrates considered as liquid waste or agro-industrial by-products of low cost and that were easy to obtain were used in the following specified concentrations: sugar cane stillage, cheese whey from fresh cheese, and cassava press water $\left(55 \% \mathrm{v} \mathrm{v}^{-1}, 70 \% \mathrm{v} \mathrm{v}^{-1}, 85 \% \mathrm{v} \mathrm{v}^{1}\right.$, and $\left.100 \% \mathrm{v} \mathrm{v}^{-1}\right)$; yeast cream from sugar cane industry $\left(20 \% \mathrm{v} \mathrm{v} \mathrm{v}^{-1}, 40 \% \mathrm{v} \mathrm{v}^{-1}, 55 \% \mathrm{v} \mathrm{v}^{-1}\right.$, and $\left.70 \% \mathrm{v} \mathrm{v}^{-1}\right)$; sugar cane molasses $\left(2 \% \mathrm{v} \mathrm{v}^{-1}\right.$, $4 \% \mathrm{v} \mathrm{v}^{-1}, 6 \% \mathrm{v} \mathrm{v}^{-1}$, and $\left.8 \% \mathrm{v} \mathrm{v} \mathrm{v}^{-1}\right)$; and Milhocina ${ }^{\circledR}$ (Corn Products Inc.) (1\% v v ${ }^{-1}, 2 \% \mathrm{v} \mathrm{v} \mathrm{v}^{-1}, 4 \% \mathrm{v} \mathrm{v}^{-}$ ${ }^{1}$, and $\left.6 \% \mathrm{v} \mathrm{v}^{-1}\right)$. Different concentrations for each substrate were obtained by dilution in distilled water, based on a study by Machado et al. (2009).

The media prepared with sugar cane stillage, yeast cream, and cheese whey was supplemented with glucose $(0.5 \%)$, and the media prepared with Milhocina ${ }^{\circledR}$ was supplemented with dextrose $(1 \%)$. Chloramphenicol (250 $\left.\mathrm{mg} \mathrm{L}^{-1}\right)$ was added to all the media to prevent bacterial contamination after autoclaving.

The $\mathrm{pH}$ of the media was standardised to 6 in all the media (Moraes et al., 2011). The media $(100 \mathrm{~mL})$ were added to $250-\mathrm{mL}$ 
Erlenmeyer flasks and autoclaved at $121^{\circ} \mathrm{C}$ and $1 \mathrm{kgf} \mathrm{cm}^{-2}$ for $30 \mathrm{~min}$.

\section{Solid media preparation}

Sorghum grains, soybean hulls and cracked corn were used in this study according to Penariol et al. (2008). The substrates were arbitrarily mixed in proportions of 80:20, 60:40, 40:60, and 20:80. These mixtures were the treatments for the experiments, and each substrate was also used individually as a comparison control.

Substrates preparation was done using previously described methods by Penariol et al. (2008). The sorghum beans were cooked in boiling distilled water at a $1: 3\left(\mathrm{w} \mathrm{v} \mathrm{v}^{-1}\right)$ ratio for 5 min over low heat. Soybean hulls and cracked wheat were soaked in distilled water at a $1: 3\left(\mathrm{w} \mathrm{v} \mathrm{v}^{-1}\right)$ ratio for $15 \mathrm{~min}$. Subsequently, the substrates were strained using a fine sieve $(1 \mathrm{~mm})$ to remove excess water, and all mixtures were prepared using dry matter mass ( $\left.\mathrm{g} \mathrm{g}^{1}\right)$.

The media (mixtures) were placed in 250-mL Erlenmeyer flasks and autoclaved at $121{ }^{\circ} \mathrm{C}$ and $1 \mathrm{kgf} \mathrm{cm}^{-2}$ for $40 \mathrm{~min}$. To standardise the amount of medium used, $50 \%-55 \%$ of the flask volume was filled with the mixtures.

\section{Biphasic system}

Solid and liquid media that provided the best results on previous assays were selected considering the joint analysis of conidia production and viability. Mycelial biomass was also considered when selecting the liquid media. When statistical analysis did not show any significant difference among treatments, was chosen the treatment that presented the higher numerical value of the fungal biomass.

The selected liquid media contained 8\% sugar cane molasses and $70 \%$ yeast cream. Three types of solid media were selected as follows: $40 \%$ sorghum grain and $60 \%$ soybean hulls; $80 \%$ sorghum grain and $20 \%$ cracked wheat; and $40 \%$ soybean hulls and $60 \%$ cracked wheat. Solid and liquid media were prepared as previously described. Treatments constituted a combination of each liquid and solid medium.

\section{Cultivation of the fungus in the liquid and solid media and in a biphasic system}

Three discs (5 $\mathrm{mm}$ in diameter) were taken from fungus cultures grown for 8 days at $25 \pm 0.5{ }^{\circ} \mathrm{C}$ in minimal modified media (pH 6) (Penariol et al., 2008) and were transferred to Erlenmeyer flasks with either liquid or solid media. Cultures were then incubated at $25 \pm 0.5^{\circ} \mathrm{C}$ for 10 days in a 12 hour photoperiod. Flasks with liquid media were kept in static cultures.

In the biphasic system, the liquid media were inoculated and incubated for 7 days as previously described. The mycelial biomass was then transferred, along with the liquid medium, into a $250 \mathrm{~mL}$ beaker and crushed for $3 \mathrm{~s}$ with an SB 40 Black \& Decker ${ }^{\circledR}$ blender. The material was then strained through a $1 \mathrm{~mm}$ sieve to standardise the mycelium fragment size. Both the mixer and the sieve were thoroughly disinfected with $96^{\circ} \mathrm{GL}$ ethanol. The suspension ( $3 \mathrm{~mL}$ ) was then transferred to Erlenmeyer flasks containing solid media, and the cultures were incubated at $25 \pm 0.5^{\circ} \mathrm{C}$ for 10 days in a 12 hour photoperiod. After this period, the production and conidia viability were evaluated.

\section{Evaluation of conidia production and viability in the liquid and solid media and in a biphasic system}

In both liquid and solid media, conidia production and viability were evaluated in all treatments except in cheese whey, where it was impossible to evaluate conidia viability due to the presence of lumps. The lumps were most likely formed by milk fat, and these lumps made observations difficult. For liquid media, mycelial biomass was also evaluated.

To evaluate the production of conidia in liquid media, the mycelial biomass formed was manually disaggregated with the aid of a glass rod for $5 \mathrm{~s}$. The medium was then vigorously agitated in a magnetic stirrer for $3 \mathrm{~min}$ using $15 \mathrm{~g}$ of glass beads, and the medium was then filtered through a $1 \mathrm{~mm}$ mesh sieve. The filtered material was then vigorously shaken, and the number of conidia was determined with the aid of a Neubauer chamber. 
The conidia production in the solid media and biphasic system was evaluated by transferring $1 \mathrm{~g}$ of the medium with grown fungus to a tube containing a $1: 1$ mixture of Tween $80^{\circledR}\left(0.1 \% ; \mathrm{v} \mathrm{v}^{-1}\right)$ and saline solution $\left(0.89 \% \mathrm{NaCl} ; \mathrm{w} \mathrm{v}^{-1}\right)$. For conidia release, the material was vigorously agitated in an electric tube shaker for $30 \mathrm{~s}$. The material was then filtered through a voile fabric to remove the solid part, and the filtrate $(1 \mathrm{~mL})$ was then transferred to a tube with $9 \mathrm{~mL}$ of the Tween $80^{\circledR}$ and saline solution mixture. After vigorous agitation in an electric shaker, the quantity of conidia present was determined with the aid of a Neubauer chamber.

To assess conidia viability in liquid media, the filtered material was centrifuged for $2 \mathrm{~min}$ at $705.6 \mathrm{G}$-force, and the pellet was resuspended in $7 \mathrm{~mL}$ of saline solution. For the solid media and biphasic system, the same suspensions employed to evaluate conidia production were used. The evaluation was performed as described by Francisco et al. (2006). Microscope slides covered with a layer of minimal Pontecorvo medium (Pontecorvo et al., 1953) whose composition was modified by Penariol et al. (2008) were used, and the conidia germination was determined after 7 hours of incubation at $25 \pm 0.5{ }^{\circ} \mathrm{C}$.

To measure dry mass, the mycelium formed in the liquid media was filtered in a Buchner funnel under a vacuum pump. The media was then dried in a muffle at $60^{\circ} \mathrm{C}$ to constant weight, and determination of the dry mass was made on an analytical scale.

\section{Statistical analysis}

All experiments were organised in a completely randomised design with four replications per treatment. Data were subjected to variance analysis using the F-test, and the averages were compared by Tukey's test at $5 \%$ probability. In the liquid media treatments, a hierarchical classification model was used to evaluate the following two factors: media and concentration within the media. The SAS (1998) program was used for carrying out the analysis.

Planta Daninha, Viçosa-MG, v. 32, n. 2, p. 255-264, 2014

\section{RESULTS AND DISCUSSION}

\section{Production of $B$. euphorbiae in liquid media}

Liquid fermentation systems have been preferred for mass production of bioherbicides (Stowell, 1991), but there are some difficulties in production of fungi by this method (Alves \& Pereira, 1998). Some fungi readily sporulate in liquid culture (Stowell, 1991). Lewia chlamidosporiformans (Vieira \& Barreto) a fungal species highly pathogen of E. heterophylla produced 1.19 x $10^{7}$ chlamydospores $\mathrm{mL}^{-1}$ in the JenkinsPrior culture medium containing yeast extract $\left(10 \mathrm{~g} \mathrm{~L}^{-1}\right)$ and sucrose $\left(40 \mathrm{~g} \mathrm{~L}^{-1}\right)$ (Vieira \& Barreto, 2010). However, other fungal species do not sporulate (Zhang \& Watson, 1997) and produce a large quantity of mycelial biomass (Roberts \& Humber, 1981).

The media prepared with sugar cane molasses promoted the highest production of fungal mycelial biomass, especially at $8 \%$, where the greatest formation of dry matter (2.18 g $100 \mathrm{~mL}^{-1}$ of medium) was observed, differing significantly from the mycelial biomass obtained in the other concentrations. Although having lower mycelial growth and biomass production than in molasses, the media containing $100 \%$ cassava press water showed substantial mycelial growth and a biomass production of $1.25 \mathrm{~g} 100 \mathrm{~mL}^{-1}$ of medium. In all media, an increase in biomass production was observed as the substrate concentration was increased (Table 1).

B. euphorbiae mycelial biomass production in cassava press water liquid medium was also evaluated by Penariol et al. (2008). They reported a small amount of biomass formation, which was most likely due to the low $\mathrm{pH}$ of the medium that was not adjusted. The highest $B$. euphorbiae mycelial biomass obtained by the authors was produced in wheat bran liquid medium, reaching a value of

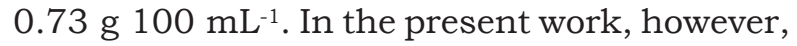
the same fungus was cultivated in sugar cane molasses resulting in a production of

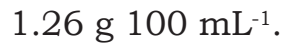

The production of $B$. euphorbiae conidia in sugar cane molasses and yeast cream was higher $(p \leq 0.01)$ than that obtained in the 
other media, with no significant differences among the tested concentrations. The 4\% and $8 \%$ molasses and $20 \%$ or $70 \%$ yeast cream were considered the most promising concentrations because they had provided higher numerical values for the production of B. euphorbiae conidia (29 and $28 \times 10^{4}$ conidia $\mathrm{mL}^{-1}$ of medium and $16 \times 10^{4}$ conidia $\mathrm{mL}^{-1}$ of medium, respectively) (Table 2) even though they did not differ significantly from the production obtained in the other concentrations.
The $B$. euphorbiae conidial production obtained in this study, especially in sugar cane molasses and yeast cream liquid media, was similar to that reported by Penariol et al. (2008) and Machado et al. (2009) in liquid culture media obtained from grains, and agroindustrial wastes and by-products. The liquid media composed of cheese whey and cassava press water showed the lowest $B$. euphorbiae conidia production. A similar result was obtained by Penariol et al. (2008) with cassava press water liquid media, although the media

Table 1 - Mycelial dry matter (g $100 \mathrm{~mL}^{-1}$ of medium) of Bipolaris euphorbiae in liquid media made from waste and agro-industrial by-products used at different concentrations after 10 days of cultivation at $25 \pm 0.5^{\circ} \mathrm{C}$ in a 12 -hour photoperiod

\begin{tabular}{|l|c|c|c|c|c|c|}
\hline \multirow{2}{*}{\multicolumn{1}{|c|}{ Liquid media }} & \multirow{2}{*}{$\begin{array}{c}\text { Treatment } \\
\text { mean }\end{array}$} & \multicolumn{4}{c|}{ Concentration } & \multirow{2}{*}{ F Test } \\
\cline { 3 - 7 } & & $\mathrm{C} 1$ & $\mathrm{C} 2$ & $\mathrm{C} 3$ & C4 & \\
\hline Sugar cane stillage & $0.55 \mathrm{C}$ & $0.7 \pm 0.10 \mathrm{a}$ & $0.5 \pm 0.07 \mathrm{a}$ & $0.5 \pm 0.02 \mathrm{a}$ & $0.5 \pm 0.03 \mathrm{a}$ & $1.49^{\mathrm{ns}}$ \\
\hline Cheese whey & $0.56 \mathrm{C}$ & $0.6 \pm 0.07 \mathrm{ab}$ & $0.38 \pm 0.04 \mathrm{~b}$ & $0.44 \pm 0.04 \mathrm{~b}$ & $0.84 \pm 0.14 \mathrm{a}$ & $1.24^{* *}$ \\
\hline Cassava press water & $0.99 \mathrm{~B}$ & $0.7 \pm 0.13 \mathrm{~b}$ & $0.9 \pm 0.09 \mathrm{ab}$ & $1.1 \pm 0.08 \mathrm{ab}$ & $1.3 \pm 0.02 \mathrm{a}$ & $4.97^{* *}$ \\
\hline Yeast cream & $0.59 \mathrm{C}$ & $0.5 \pm 0.08 \mathrm{a}$ & $0.6 \pm 0.06 \mathrm{a}$ & $0.5 \pm 0.05 \mathrm{a}$ & $0.7 \pm 0.15 \mathrm{a}$ & $1.14^{\mathrm{ns}}$ \\
\hline Sugar cane molasses & $1.26 \mathrm{~A}$ & $0.4 \pm 0.05 \mathrm{~d}$ & $1.1 \pm 0.14 \mathrm{c}$ & $1.4 \pm 0.26 \mathrm{~b}$ & $2.2 \pm 0.16 \mathrm{a}$ & $58.46^{* *}$ \\
\hline Milhocina & $0.43 \mathrm{C}$ & $0.2 \pm 0.02 \mathrm{~b}$ & $0.4 \pm 0.04 \mathrm{ab}$ & $0.4 \pm 0.04 \mathrm{ab}$ & $0.7 \pm 0.08 \mathrm{a}$ & $3.01^{*}$ \\
\hline F test & $42.46^{* *}$ & & & & & \\
\hdashline SEM & 0.01 & & & & & \\
\hline
\end{tabular}

Original value. Means followed by at least one common capital letter in a column or small letter in a line do not differ by Tukey's test, ( $\mathrm{p} \geq 0.05$ ). Concentrations: Sugar cane stillage, cheese whey and cassava press water: C1: 55\%, C2: 70\%, C3: 85\% and C4: 100\%. Yeast cream: C1: 20\%, C2: 40\%, C3: 55\% and C4: 70\%; Sugar cane molasses: C1: 2\%, C2: 4\%, C3: 6\% and C4: 8\%. Milhocina ${ }^{\circledR}$ : C1: 1\%, C2: $2 \%, \mathrm{C} 3: 4 \%$ and $\mathrm{C} 4: 6 \%$. ${ }^{\text {ns }}$ Not significant; $* *$ Significant at $1 \%$ probability; $*$ Significant at $5 \%$ probability. SEM: Standard error medium.

Table 2 - Conidia production (x $10^{4}$ conidia $\mathrm{mL}^{-1}$ of medium) of Bipolaris euphorbiae in liquid media made from waste and agroindustrial by-products used at different concentrations after 10 days of cultivation at $25 \pm 0.5^{\circ} \mathrm{C}$ in a 12-hour photoperiod

\begin{tabular}{|c|c|c|c|c|c|c|}
\hline \multirow{2}{*}{ Liquid media } & \multirow{2}{*}{$\begin{array}{c}\text { Treatments } \\
\text { means }\end{array}$} & \multicolumn{4}{|c|}{ Concentration } & \multirow{2}{*}{ F Test } \\
\hline & & $\mathrm{C} 1$ & $\mathrm{C} 2$ & $\mathrm{C} 3$ & $\mathrm{C} 4$ & \\
\hline Sugar cane stillage & $5.8 \mathrm{BC}$ & $11.0 \pm 0.26 \mathrm{a}$ & $6.0 \pm 0.21 \mathrm{a}$ & $4.3 \pm 0.15 \mathrm{a}$ & $2.0 \pm 0.14 \mathrm{a}$ & $0.64^{\mathrm{ns}}$ \\
\hline Cheese whey & $1.5 \mathrm{D}$ & $1.7 \pm 0.10 \mathrm{a}$ & $2.3 \pm 0.17 \mathrm{a}$ & $1.0 \pm 1.39 \mathrm{~b}$ & $1.0 \pm 0.00 \mathrm{~b}$ & $4.77 * *$ \\
\hline Cassava press water & $3.2 \mathrm{CD}$ & $3.3 \pm 0.12 \mathrm{a}$ & $3.7 \pm 0.26 \mathrm{a}$ & $3.3 \pm 0.23 a$ & $2.7 \pm 0.18 \mathrm{a}$ & $0.03^{\mathrm{ns}}$ \\
\hline Yeast cream & $15.0 \mathrm{AB}$ & $16.0 \pm 0.19 \mathrm{a}$ & $13.0 \pm 0.06 \mathrm{a}$ & $15.0 \pm 0.09 \mathrm{a}$ & $16.0 \pm 0.16 \mathrm{a}$ & $0.01^{\mathrm{ns}}$ \\
\hline Sugar cane molasses & $23.0 \mathrm{~A}$ & $14.0 \pm 0.11 \mathrm{a}$ & $29.0 \pm 0.13 a$ & $22.0 \pm 0.11 \mathrm{a}$ & $28.0 \pm 0.19 a$ & $0.17^{\text {ns }}$ \\
\hline Milhocina $^{\circledR}$ & $7.5 \mathrm{ABC}$ & $15.0 \pm 0.26 \mathrm{a}$ & $4.7 \pm 0.06 \mathrm{a}$ & $8.3 \pm 0.19 a$ & $2.7 \pm 0.06 \mathrm{a}$ & $0.58^{\text {ns }}$ \\
\hline F test & $10.75^{* *}$ & & & & & \\
\hline SEM & 0.32 & & & & & \\
\hline
\end{tabular}

Original value and statistical analysis of conidia production was perfomed with data transformed in a $\log (\mathrm{x})$ scale. Means followed by at least one common capital letter in a column or small letter in a line do not differ by Tukey's teste, ( $\mathrm{p} \geq 0.05)$. Concentrations: Sugar cane stillage, cheese whey and cassava press water: $\mathrm{C} 1: 55 \%, \mathrm{C} 2: 70 \%, \mathrm{C} 3: 85 \%$ and $\mathrm{C} 4: 100 \%$; Yeast cream: C1: 20\%, C2: 40\%, C3: 55\% and C4: 70\%; Sugar cane molasses: C1: 2\%, C2: 4\%, C3: 6\% and C4: $8 \%$. Milhocina ${ }^{\circledR}: \mathrm{C} 1: 1 \%, \mathrm{C} 2: 2 \%, \mathrm{C} 3: 4 \%$ and C4: 6\%. ${ }^{\mathrm{n} N \mathrm{Not}}$ significant; $* *$ Significant at $1 \%$ probability. SEM: Standard error medium. 
they used had a $\mathrm{pH}$ value of 4.3. However, the cassava press water liquid media at an adjusted $\mathrm{pH}$ of 6.5 was more suitable for conidia production (Machado et al., 2009).

The viability test results showed that only the conidia produced in Milhocina ${ }^{\circledR}$ and cassava press water presented a lower germination capacity $(89.1 \%$ and $91.2 \%$, respectively), differing on average ( $p \leq 0.05)$ from the conidia viability obtained in all other media (Table 3). However, the germination percentage obtained with these two media can be considered satisfactory in terms of quality control of fungus production. For all other media, the viability was greater than 97\% (Table 3). The liquid media containing molasses, yeast cream, and sugar cane stillage were the ones that provided the best conidia viability values, which differed from the results obtained by Penariol et al. (2008), who found no effect of the liquid medium composition on conidia viability.

The joint analysis of the three evaluated parameters suggested that the sugar cane molasses media is the most favourable for $B$. euphorbiae production.

\section{Production of $B$. euphorbiae in solid media}

Fungus cultivation in solid media is the most widely used production form because it does not require sophisticated technology (Alves \& Pereira, 1998). According to Penariol et al. (2008) sorghum grains and soybean hulls provide the best results for sporulation and viability of $B$. euphorbiae, and cracked corn favours viability.

In the media prepared with either sorghum grain and soybean hulls, or with soybean hulls and cracked wheat, no difference in conidia production was observed as a function of the various utilised mixtures. In both media, the mixture containing $40-60 \%$ of the components of each medium can be highlighted, as provided higher numerical values of conidial production $\left(2.3 \times 10^{7}\right.$ conidia $\mathrm{g}^{-1}$ of medium and $1.5 \times 10^{7}$ conidia $\mathrm{g}^{-1}$ of medium, respectively), but without statistical differences from production obtained with other mixtures. In the media made with sorghum grain and cracked wheat, the mixtures influenced fungus conidia production. The proportion of $80: 20 \%$ of the medium components can be emphasized because it provided the highest numerical value of conidia production $\left(1.7 \times 10^{7}\right.$ conidia $\mathrm{g}^{-1}$ ), even though it did not differ significantly from the production obtained by the 100:0, 60:40, and 20:80\% mixtures (Table 4).

Culture medium selection is an important aspect to be considered in production (Khalil et al., 1985). Several substrates were evaluated to obtain large quantities of viable propagules (E1 Damir, 2006; Wenzel et al., 2006; Jegathambigai et al., 2010). The conidial production of Alternaria alternata f. sp.

Table 3 - Viability (\%) of Bipolaris euphorbiae conidia produced in liquid media made from waste and agro-industrial by products used at different concentrations after 10 days of cultivation at $25 \pm 0.5^{\circ} \mathrm{C}$ in a 12-hour photoperiod

\begin{tabular}{|c|c|c|c|c|c|c|}
\hline \multirow{2}{*}{ Liquid media } & \multirow{2}{*}{ Treatments means } & \multicolumn{4}{|c|}{ Concentration } & \multirow{2}{*}{ F Test } \\
\hline & & $\mathrm{C} 1$ & $\mathrm{C} 2$ & $\mathrm{C} 3$ & $\mathrm{C} 4$ & \\
\hline Sugar cane stillage & $97.4 \mathrm{AB}$ & $98.4 \mathrm{a}$ & $95.8 \mathrm{a}$ & $97.6 \mathrm{a}$ & $97.9 \mathrm{a}$ & $0.10^{\mathrm{ns}}$ \\
\hline Cassava press water & $91.2 \mathrm{BC}$ & $86.3 a$ & $92.5 \mathrm{a}$ & $87.7 \mathrm{a}$ & $98.2 \mathrm{a}$ & $0.27^{\mathrm{ns}}$ \\
\hline Yeast cream & $99.1 \mathrm{~A}$ & $98.9 \mathrm{a}$ & $98.7 \mathrm{a}$ & $99.4 \mathrm{a}$ & $99.1 \mathrm{a}$ & $0.01^{\mathrm{ns}}$ \\
\hline Sugar cane molasses & $99.7 \mathrm{~A}$ & $99.6 \mathrm{a}$ & $99.7 \mathrm{a}$ & $99.8 \mathrm{a}$ & $99.7 \mathrm{a}$ & $0.00^{\mathrm{ns}}$ \\
\hline Milhocina $^{\circledR}$ & $89.1 \mathrm{C}$ & $94.6 \mathrm{a}$ & $95.5 \mathrm{a}$ & $78.5 \mathrm{~b}$ & $88.0 \mathrm{ab}$ & $4.76^{* *}$ \\
\hline F test & $7.21 * *$ & & & & & \\
\hline SEM & 3.58 & & & & & \\
\hline
\end{tabular}

Original value and statistical analysis of viability was done with data transformed in a $\arcsin \mathrm{x} / 100$ scale. Means followed by at least one common capital letter in a column or small letter in a line do not differ by Tukey's test, $(\mathrm{p} \geq 0.05)$. Concentrations: Sugar cane stillage and cassava press water: $\mathrm{C} 1: 55 \%, \mathrm{C} 2: 70 \%, \mathrm{C} 3: 85 \%$ and $\mathrm{C} 4: 100 \%$; Yeast cream: $\mathrm{C} 1: 20 \%, \mathrm{C} 2: 40 \%, \mathrm{C} 3: 55 \%$ and $\mathrm{C} 4: 70 \%$; Sugar

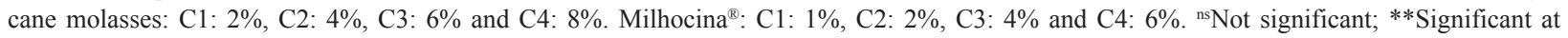
$1 \%$ probability; SEM: Standard error medium. 
Table 4 - Conidial production and viability of Bipolaris euphorbiae in solid media prepared with mixtures of substrates at various concentrations after 10 days of cultivation at $25 \pm 0.5^{\circ} \mathrm{C}$ in a 12-hour photoperiod

\begin{tabular}{|c|c|c|c|}
\hline \multirow{2}{*}{ Culture medium } & \multirow{2}{*}{ Mixture and concentration } & Conidia production & Viability \\
\hline & & (number $\times 10^{7} \mathrm{~g}^{-1}$ of medium) & $(\%)$ \\
\hline \multirow{6}{*}{$\begin{array}{l}\text { Sorghum grain (SG) } \\
\quad \text { and } \\
\text { Soybean hulls }(\mathrm{SH})\end{array}$} & $100 \% \mathrm{SG}+0 \% \mathrm{SH}$ & $1.37 \pm 0.09 \mathrm{~A}$ & $99.9 \pm 0.08 \mathrm{~A}$ \\
\hline & $80 \% \mathrm{SG}+20 \% \mathrm{SH}$ & $1.15 \pm 0.15 \mathrm{~A}$ & $99.9 \pm 0.07 \mathrm{~A}$ \\
\hline & $60 \% \mathrm{SG}+40 \% \mathrm{SH}$ & $1.45 \pm 0.12 \mathrm{~A}$ & $100.0 \pm 0.03 \mathrm{~A}$ \\
\hline & $40 \% \mathrm{SG}+60 \% \mathrm{SH}$ & $2.30 \pm 0.16 \mathrm{~A}$ & $99.8 \pm 0.06 \mathrm{~A}$ \\
\hline & $20 \% \mathrm{SG}+80 \% \mathrm{SH}$ & $1.3 \pm 0.15 \mathrm{~A}$ & $99.9 \pm 0.05 \mathrm{~A}$ \\
\hline & $0 \% \mathrm{SG}+100 \% \mathrm{SH}$ & $1.40 \pm 0.06 \mathrm{~A}$ & $99.9 \pm 0.04 \mathrm{~A}$ \\
\hline \multicolumn{2}{|l|}{$\mathrm{F}$ Test } & $1.43^{\mathrm{ns}}$ & $1.40^{\mathrm{ns}}$ \\
\hline \multirow{6}{*}{$\begin{array}{l}\text { Sorghum grain }(\mathrm{SG}) \\
\quad \text { and } \\
\text { Cracket wheat }(\mathrm{CW})\end{array}$} & $100 \% \mathrm{SG}+0 \% \mathrm{CW}$ & $1.17 \pm 0.03 \mathrm{~A}$ & $99.9 \pm 0.03 \mathrm{~A}$ \\
\hline & $80 \% \mathrm{SG}+20 \% \mathrm{CW}$ & $1.70 \pm 0.07 \mathrm{~A}$ & $99.9 \pm 0.09 \mathrm{~A}$ \\
\hline & $60 \% \mathrm{SG}+40 \% \mathrm{CW}$ & $1.25 \pm 0.09 \mathrm{~A}$ & $99.9 \pm 0.03 \mathrm{~A}$ \\
\hline & $40 \% \mathrm{SG}+60 \% \mathrm{CW}$ & $0.45 \pm 0.30 \mathrm{C}$ & $100.0 \pm 0.03 \mathrm{~A}$ \\
\hline & $20 \% \mathrm{SG}+80 \% \mathrm{CW}$ & $1.37 \pm 0.31 \mathrm{AB}$ & $100.0 \pm 0.03 \mathrm{~A}$ \\
\hline & $0 \% \mathrm{SG}+100 \% \mathrm{CW}$ & $0.27 \pm 0.05 \mathrm{BC}$ & $99.9 \pm 0.15 \mathrm{~A}$ \\
\hline \multicolumn{2}{|l|}{$\mathrm{F}$ Test } & $2.71 *$ & $0.76^{\mathrm{ns}}$ \\
\hline \multirow{6}{*}{$\begin{array}{l}\text { Soybean hulls }(\mathrm{SH}) \\
\text { and } \\
\text { Cracket wheat }(\mathrm{CW})\end{array}$} & $100 \% \mathrm{SH}+0 \% \mathrm{CW}$ & $1.07 \pm 0.06 \mathrm{~A}$ & $99.9 \pm 0.03 \mathrm{~A}$ \\
\hline & $80 \% \mathrm{SH}+20 \% \mathrm{CW}$ & $1.10 \pm 0.05 \mathrm{~A}$ & $100.0 \pm 0.03 \mathrm{~A}$ \\
\hline & $60 \% \mathrm{SH}+40 \% \mathrm{CW}$ & $1.00 \pm 0.16 \mathrm{~A}$ & $100.0 \pm 0.03 \mathrm{~A}$ \\
\hline & $40 \% \mathrm{SH}+60 \% \mathrm{CW}$ & $1.50 \pm 0.11 \mathrm{~A}$ & $100.0 \pm 0.03 \mathrm{~A}$ \\
\hline & $20 \% \mathrm{SH}+80 \% \mathrm{CW}$ & $0.57 \pm 0.09 \mathrm{~A}$ & $100.0 \pm 0.03 \mathrm{~A}$ \\
\hline & $0 \% \mathrm{SH}+100 \% \mathrm{CW}$ & $0.80 \pm 0.10 \mathrm{~A}$ & $99.9 \pm 0.09 \mathrm{~A}$ \\
\hline \multicolumn{2}{|l|}{ F Test } & $0.81^{\mathrm{ns}}$ & $0.81^{\mathrm{ns}}$ \\
\hline \multicolumn{2}{|l|}{ CV $(\%)$} & 4.11 & 0.12 \\
\hline \multicolumn{2}{|l|}{ SEM } & 0.14 & 0.59 \\
\hline
\end{tabular}

Original value and statistical analysis of conidia production and viability were done with data transformed in a log $(\mathrm{x})$ and arcsin $\mathrm{x} / 100$ scale, respectively. Means followed by at least one common letter in the column do not differ by Tukey's test, ( $\mathrm{p} \geq 0.05)$. ${ }^{\mathrm{ns}} \mathrm{Not}$ significant; *Significant at 5\% probability; CV: Coefficient of variation. SEM: Standard error medium.

sphenocleae (1912) was maximised in a solid medium prepared with sorghum seeds (Masangkay et al., 2000). Solid substrates with relatively low protein content, such as seeds of sorghum, millet, maize, rice, and maize stalks, promoted A. alternata sporulation, with rice, wheat, sorghum, and maize producing the most conidia (Babu et al., 2004). Zhao \& Shamoun (2006) showed that sporulation and conidial discharge of Valdensinia heterodoxa Peyronel, a fungal bioagent for control of Gaultheria shallon (salal), was greatly stimulated by growth in solid media with the greatest number of discharged conidia observed from wheat bran and wheat bran-salal. Marchiori et al. (2001) reported that V8 agar with rice grains and sorghum used as substrate provides greater $B$. euphorbiae conidia production when compared to agar with sunflower seeds as substrate.

In search of alternative substrates, Penariol et al. (2008) obtained large conidial production of the fungus using sorghum grain and soybean hulls. In our study, the mixture between these substrates and cracked wheat in different proportions caused an increase in spore production amounting to $10^{7}{\text { conidia } \mathrm{g}^{-1}}^{-1}$ of substrate, whereas in the Penariol and coworkers study yield was about $10^{6}$ conidia $^{-1}$ of substrate. The enhanced surface area, lack of particle aggregation, equilibrium of nutrient content, and appropriate moisture provided by the mixture of these substrates probably were able to promote the fungus sporulation and to produce large amount of conidia. 
Similar findings were reported by Shabana et al. (2010) for Dactylaria higginsii, a fungal bioagent used to control the purple nutsedge and yellow nutsedge, whose conidia production was higher when the fungus was grown on purple nutsedge, followed by bahiagrass, sorghum $x$ sudangrass, yellow nutsedge, and cogongrass hays.

B. euphorbiae conidia viability was not influenced $(p \geq 0.05)$ by culture media composed of different substrates in various proportions. Conidia viability greater than $90 \%$ is recommended for use in management programmes, which was verified for all the conidia produced in all media where viability was greater than 99\% (Table 4).

Conidia produced in solid media in this study showed high viability (99.7\% to $100 \%)$, which was similar to the results achieved by Penariol et al. (2008). In both studies the results were better than those found by Marchiori et al. (2001) who obtained 90\% viability for conidia produced in media with popcorn kernels, corn with rice, corn with sorghum, sorghum with rice, and rice alone.

\section{Production of B. euphorbiae in the biphasic system}

The biphasic cultivation can be an advantageous method to increase production of conidial fungi in industrial production systems (Guillon, 1997). Several authors have reported an increase in conidial production of other fungi by the biphasic cultivation system (Nirmala et al., 2005; Derakhshan et al., 2008; Machado et al., 2010).

However, the results obtained in this study did not show an increase in $B$. euphorbiae production by this method. The combination of yeast cream with mixtures of soybean hulls and cracked wheat or sorghum grain and soybean hulls resulted in the highest value of conidial production (1.4 and $1.3 \times 10^{7}$ conidia $\mathrm{g}^{-1}$ of substrate, respectively) but differed only from the combination of molasses with a mixture of sorghum grain and soybean hulls $\left(0.7 \times 10^{7}\right.$ conidia $\mathrm{g}^{-1}$ of substrate $)$ (Table 5).

Combinations that used yeast cream as liquid media provided the highest numerical production values when compared to combinations with molasses (Table 5). However, all values were lower than those obtained in conventional solid media (Table 4) indicating that conidia production was not increased by the biphasic system compared to conventional culture on solid media. The substrates used in this study were different from others, thus making comparisons difficult. The lack of an increase in production may be due to the insufficient amount of inoculum used $(3 \mathrm{~mL})$ and/or incubation period in liquid media (7 days), which probably did not allow for sufficient biomass production to rapidly colonise the solid media and promote sporulation. Therefore, these aspects must be further investigated.

Table 5 - Conidial production and viability of Bipolaris euphorbiae after biphasic cultivation for 10 days at $25 \pm 0.5^{\circ} \mathrm{C}$ in a 12 -hour photoperiod

\begin{tabular}{|c|c|c|}
\hline \multirow{2}{*}{ Biphasic combination (liquid/solid media) } & Conidia production & Viability \\
\hline & $\left(\mathrm{x} 10^{7} \mathrm{~g}^{-1}\right.$ solid medium $)$ & $(\%)$ \\
\hline Sugar cane molasses $(8 \%)$ / Sorghum grain + Soybean hulls $(40: 60 \%)$ & $0.7 \mathrm{~B}$ & $99.9 \mathrm{~A}$ \\
\hline Sugar cane molasses $(8 \%)$ / Sorghum grain + Cracked wheat $(80: 20 \%)$ & $0.8 \mathrm{AB}$ & $99.7 \mathrm{~A}$ \\
\hline Sugar cane molasses $(8 \%)$ / Soybean hulls + Cracked wheat $(40: 60 \%)$ & $1.0 \mathrm{AB}$ & $99.9 \mathrm{~A}$ \\
\hline Yeast cream $(70 \%)$ / Sorghum grain + Soybean hulls $(40: 60 \%)$ & $1.3 \mathrm{AB}$ & $99.9 \mathrm{~A}$ \\
\hline Yeast cream $(70 \%)$ / Sorghum grain + Cracked wheat $(80: 20 \%)$ & $1.0 \mathrm{AB}$ & $99.7 \mathrm{~A}$ \\
\hline Yeast cream $(70 \%)$ / Soybean hulls + Cracked wheat $(40: 60 \%)$ & $1.4 \mathrm{~A}$ & $99.9 \mathrm{~A}$ \\
\hline F Test & $4.21^{*}$ & $1.01^{\mathrm{ns}}$ \\
\hline $\mathrm{CV}(\%)$ & 1.22 & 0.31 \\
\hline SEM & 0.11 & 0.18 \\
\hline
\end{tabular}

Original values and statistical analysis of conidia production and viability were performed with data transformed in a $\log (\mathrm{x})$ and $\arcsin$ $\mathrm{x} / 100$ scale, respectively. Means followed by at least one common letter in the column do not differ by the Tukey's test, ( $\mathrm{p} \geq 0.05$ ). ${ }^{\mathrm{n}}$ Not significant; * Significant at 5\% propability. CV: Coefficient of variation. SEM: Standard error medium. 
Biphasic cultivation did not affect conidia viability, which remained greater than $99 \%$. Moreover, no significant differences among the treatments were observed (Table 5), which was also observed in conventional solid media production.

The introduction of $B$. euphorbiae as a biocontrol agent of $E$. heterophylla in soybean fields depends on the production of fungal conidia in large amounts. The liquid media prepared from agro-industrial waste or by-products are not efficient for the production of conidia of $B$. euphorbiae, but produce a large fungus mycelial biomass. This production is influenced by the concentration of the substrates used to prepare the media. Cultivation on solid medium provided an efficient system for production of conidia. Mixtures of grains and grain derivatives increased the production of viable conidia and showed to be a feasible system for large-scale production of conidia aiming to formulate a bioproduct for the control of E. heterophylla in soybeans fields. However, the combination of liquid and solid media in biphasic system cultivation was not effective for increasing conidia production of $B$. euphorbiae.

\section{ACKNOWLEDGEMENT}

The authors would like to thank the National Council for Scientific and Technologic Development in Brazil (Conselho Nacional de Desenvolvimento Científico e Tecnológico (CNPq)), for financial support of the first author's graduate studies.

\section{LITERATURE CITED}

ALVES, S. B.; PEREIRA, R. M. Produção de fungos entomopatogênicos. In: ALVES, S. B. Controle microbiano de insetos. Piracicaba: FEALQ, 1998. p. 845-869.

BABU, R. M.; SAJEENA, A.; SEETHARAMAN, K. Solid substrate for production of Alternaria alternata conidia: a potential mycoherbicide for the control of Eichhornia crassipes (water hyacinth). Weed Res., v. 44, n. 4, p. 298-304, 2004.

DERAKHSHAN, A. et al. Evaluation of different media and methods of cultivation on the production and vaibility of entomopathogenic fungi, Verticillium lecanii (Zimm.) Viegas. Pak. J. Biol. Sci., v. 11, n. 11, p. 1506-1509, 2008.
EL DAMIR, M. Effect of growing media and water volume on conidial production of Beauveria bassiana and Metarhizium anisopliae. J. Biol. Sci., v. 6, n. 2, p. 269-274, 2006.

FRANCISCO, N. E. et al. Influence of culture media in viability test of conidia of entomopathogenic fungi. Ci. Rural, v. 36, n. 4, p. 1309-1312, 2006.

GUILLON, M. Production of biopesticides: scale up and quality assurance. In: BRITISH CROP PRODUCTION COUNCIL SYMPOSIUM, 68., 1997, Farnham. Proceedings... Farnham: The British Crop Protection Council, 1997. p. 151-162.

JEGATHAMBIGAI, V.; WIJERATNAM, R. S. W.; WIJESUBDERA, R. L. C. Effect of Trichoderma sp. on Sclerotium rolfsii, the causative agent of collar rot on Zamioculcas zamiifolia and on farm method to mass produce Trichoderma species. Plant Pathol. J., v. 9, n. 2, p. 47-55, 2010.

JENKINS, N. E.; GOETTEL, M. S. Methods for massproduction of microbial control agents for grasshoppers and locusts. Memoirs Entomol. Soc. Canada, v. 71, n. 1, p. 37-48, 1997.

KHALIL, S. K.; SHAN, M. A.; NAEEM, M. Laboratory on the compatibility of the entomopathogenic fungus Verticillium lecanii with certain pesticides. Agric. Ecosyst. Environ., v. 13 , n. 3-4, p. 329-334, 1985.

KOLOMBET, L. V. et al. Development of an extended shelflife, liquid formulation of the biofungicide Trichoderma asperellum. World J. Microbiol. Biotechnol., v. 24, n. 1, p. 123-131, 2008.

MACHADO, A. C. R. et al. Resíduos e subprodutos agroindustriais e grãos como substratos para produção do fungo entomapatogênico Lecanicillium lecanii. Bragantia, v. 68, n. 3, p. 703-714, 2009.

MACHADO, A. C. R. et al. Production technology for entomopathogenic fungus using a biphasic culture system. Pesq. Agropec. Bras., v. 45, n. 10, p. 1157-1163, 2010.

MARCHIORI, R. et al. Comparison of culture media for the mass production of Bipolaris euphorbiae and its impact on Euphorbia heterophylla dry matter accumulation. Summa Phytopathol., v. 27, n. 4, p. 428-432, 2001.

MASANGKAY, R. F. et al. Solid substrate production of Alternaria alternata f. sp. sphenocleae conidia. Biocontrol Sci. Technol., v. 10, n. 4, p. 399-409, 2000.

MORAES, C.; MONTEIRO, A. C.; MOCHI, D. A. Reaction of Bipolaris euphorbiae to environmental factors and its tolerance to solar and ultraviolet radiation. World J.

Microbiol. Biotechnol., v. 27, n. 6, p. 1449-1456, 2011. 
NIRMALA, R. B. et al. Growth parameters of some isolates of entomofungal pathogens and production of dust-free spores on rice medium. J. Biol. Control, v. 19, n. 2, p. 121-128, 2005.

PENARIOL, M. C. et al. Produção de Bipolaris euphorbiae em meios de cultura sólidos e líquidos obtidos de grãos e resíduos agroindustriais. Bragantia, v. 67, n. 4, p. 805-814, 2008.

PONTECORVO, G. et al. The genetic of Aspergillus nidulans. Adv. Genetics, v. 5, n. 2, p. 141-238, 1953.

ROBERTS, D. W.; HUMBER, R. A. Entomogenous fungi. In: COLE, G. T.; KENDRICK, B. Biology of conidial fungi. New York: Academic Press, 1981. p. 201-236.

SAS Institute Inc. SAS/STAT - User's Guide: statisticversion 6.12, Cary: 1998. 846 p.

SHABANA, Y. M. et al. Production and application of the bioherbicide agent Dactylaria higginsii on organic substrates. Biol. Control, v. 54, n. 3, p. 159-165, 2010.

STOWELL, L. J. Submerged fermentation of biological herbicides. In: TEBEEST, D. O. Microb. control weeds. New York: Chapman \& Hall, 1991. p. 225-261.
TEBEEST, D. O. Biological control of weeds with microbial herbicides. Fitopatol. Bras., v. 9, n. 3, p. 443-453, 1984.

VIEIRA, B. S.; BARRETO, R. W. Liquid culture production of chlamydospores of Lewia chlamidosporiformans

(Ascomycota: Pleosporales), a mycoherbicide candidate for wild poinsettia. Austr. Plant Pathol., v. 39, n. 2, p. 154-160, 2010.

VIDAL, R. A.; FLECK, N. G. Análise do risco da ocorrência de biótipos de plantas daninhas resistentes aos herbicidas. Planta Daninha, v. 15, n. 2, p. 152-161, 1997.

WENZEL, I. M.; MONTEIRO, A. C.; PEREIRA, G. T. Produção de conídios de Lecanicillium lecanii em substratos sólidos e líquidos obtidos de grãos. Científica, v. 34, n. 1, p. 7-17, 2006.

ZHANG, W. M.; WATSON, A. K. Characterization of growth and conidia production of Exserohilum monoceras on different substrates. Biocontrol Sci. Technol., v. 7, n. 1, p. $75-86,1997$.

ZHAO, S.; SHAMOUN, S. F. The effects of culture media, solid substrates, and relative humidity on growth, sporulation and conidial discharge of Valdensinia heterodoxa.

Mycol. Res., v. 110, n. 11, p. 1340-1346, 2006. 